\title{
Man and Cosmos from the Christian Theology perspective
}

\author{
Fr. PhD. Marin BugIUlesCU \\ "Valahia" University of Târgovişte, \\ ROMANIA \\ E-mail: m_bugiulescu@yahoo.com
}

\begin{abstract}
The purpose of this paper is to analyse the theological reflection on the relationship between man and cosmos. The origin of the world and man is connected to God; God is the Creator and consequently the Author of them both. Unlike dualistic materialistic thinking, according to the Christian conception the whole cosmos is created by God. In search for the cosmos an important chapter was granted for man, considered to be a synthesis of the world. Man, from the theological perspective, is the personal, rational, free, and speaking being that has - through the image of God according to which he has been created -, the tension after perfection. But it pertains exclusively to the relationship with Christ in the light of Whom he really knows himself, and by knowing himself he recognizes the infinite beauty of the Archetype. This is the existential-theological truth, which the content of this paper emphasizes, according to the Bible and patristic teaching.
\end{abstract}

Keywords: man; world; cosmos; philosophy; theology; Christianity;

\section{INTRODUCTION}

According to Christian teachings, the world is created by God "out of nothing" and in time, which shows that it did not pre-exist. The world, the cosmos, the universe as described by the Christian Revelation appears as a space imprinted by the divine energies because it is basically the work of the Holy Trinity, the only source from which the power of life springs and providentially sustains everything all that exists. The world is the updating to plan of God in space and time. The world as a whole is dynamic, alive, in continuing moving, a reality defined by the notion of "creation in the state of creation", but not in the evolutionary sense, but in the sense of becoming and renewing, or as an incomplete situation, once all tend to perfection, to transfiguration, that is the final state.

From the various language words used to define the work and result of God, for example, the creation or nature, that is, what was born, or cosmos, which means ordaining, and in broader sense the order of the universe; or as the Latin "universum", i.e. etymologically, turned, oriented so as to form a whole, a coordinated ensemble. The most appropriate for creation is the Latin word "lumen", which means light, and is explained in and through the Light of the world - Jesus Christ, the Son of God who became man (cf. John 8:12). Man cannot conceive beyond cosmic nature. Nature is not only the condition of the existence of the unique man, but also of human solidarity. Nature appears in a very clear way as the environment by which man can do good or evil by progressing or regressing from the material and spiritual point of view. 


\section{Man and cosmos. Ancient philosophical landmarks}

The notion of cosmos ( $\kappa \omega \sigma \mu \omega \varsigma$ - order, harmony) occurs in ancient Greek thought, where the Demiurge gives shape to amorphous matter, pre-existing matter, which before being ordered is under total chaos. This is a dualist materialistic conception that brings to the origin of the world two principles: divinity and matter. The ancient Greeks believed that the world as we know it, with its laws, has not always existed, but it originated from an initial chaos, to a prehistoric phase in which there was no distinction and differentiation, in which their things and their attributes, phenomena and beings had not existed as such. The principle of all things is the "unity" from which the animated universe is born (Diogenes Laertios ${ }^{1}$ ). This unity, seen as a struggle of opposites, is according to Heraclitus, the Supreme Harmony, or Logos.

"This logos-principle, though hidden and accessible only to intelligence, is still material, as it results from the identification of the heroclitian logos with cosmic fire"2.

Image of chaos, as an undifferentiated mixture, in the philosophy appears for the first time at Anaxagoras of Clazomene, who claims that the order of creation is given by Reason, Nous - Intelligence, but Intelligence is not part of the world, because then it would have been so Imperfect like these, so the Intelligence is independent of the world, not mixing with creation, but it moves and orders all things.

At origin of the "cosmos" idea, there were the simple observations made on the phenomena of nature. The notion of cosmos opposes the concept of $\operatorname{chaos}^{3}$. The big and central idea of ancient Greek Philosophy is concentrated in the notion of cosmos-order, which gives the unity of the world, harmony but also determinism, as well as the preoccupation to understand the origin of the world and its order in search a divinity as a unitary principle Unchangeable, to give him real existence. The relationship between the actual existence of the creation ones is under a continual contradictory struggle. The movement of things makes Heraclitus consider their existence to be apparent; And Parmenides argues that true existence has the unchangeable being, that is, Supreme Reason, which is not related to the things of the world. Plato, attempts to reconcile these two contradictory views, through the theory of ideas or the world of eternal ideas, which serve as the standard, model, the sensible world, of which the greatest is the idea of Good ${ }^{4}$, identified by Plotinus (3rd century AD) .) With God, the infinite, the simple one that transcends time and space through emanation. Thus, Plato considers the birth of the world somewhat of something that can be called God. Even if he attributes a divine identity to the world, it is devoid of content, of real existence.

John Sallis says the logical term in Greek thought has two meanings, namely, "to say, to speak" and "to mediate the thing together" ${ }^{5}$. Aristotle, in opposition to Plato, gives an substratum ontological, real to individual things, claiming that the only thing that exists is

\footnotetext{
${ }^{1}$ Diogenes Laertios, Viaţa şi doctrinele filosofilor (Life and Doctrines of the Philosophers), Academia Română, Bucharest, 1963

2 Francis E. Peters, Termenii filosofiei grecesti (The terms of Greek Philosophy), 2nd edit., Bucharest, Humanitas, 1997, p. 161.

3 Jean Pierre Lonchamp, Stiinţă şi credinţă (Science and Faith), transl. by Magda Stavinschi, Eonul Dogmatic, Bucharest, 2003, pp. 18-31; John F. Haught, Ştiinţă şi religie (Science and Religion), Eonul Dogmatic, Bucharest, 2002, pp. 194- 220.

${ }^{4}$ C. Narly, Antologie ftlosofica, (Philosophical Anthology), Bucharest, Casa Scoalelor, 1943, p. 36

5 John Sallis, Being and Logos-Reading the platonic dialogues, Bloomington, Indiana University Press, 1996, p. 7.
} 
the individual. But through this, the ontology of the material outside of God, which coincides with the ones created, cannot be sustained, for the individual ends tragically with his death. Aristotle sought to solve the fundamental problem of the Greek philosopher as to how a Being is in substance, and God as pure thinking is out of the world in an eternal state.

The philosophical conception of an impersonal God makes him merge with the created ones, or those created to be an emanation from Him, as in pantheism. God is not only an ordering existence, but a Creator, who brings to existence "out of nothing", all being made in order to promote the crown of creation i.e. man. He is not connected to the world in the form of Plato's "creation", that is, as an identification of the sensible and intelligible world; nor the confusion with the seminal logos, or the generating principle of the Universe, a concept promoted by the Stoics, who taught that the reason of creation is inanimate and unconscious, exerted by the influence of the one who imposes it, that is to say the Logos, as generating reason concurrent with creation; nor by emanation as Plotinus thinks. But God as the Absolute thrice-personal-Being is the transcendent and immanent source, whose rationality is put with measure in those created by uncreated divine energies, theologically called with the concept of grace.

\section{Man and the world from the Christian Theology perspective}

The world, created in time and of nothing, is the work of divine love. God is revealing in the world to man willingly and freely, so man's existence was necessary to receive and perceive divinity. The Absolute divine Existence has no internal or external necessity, a fact expressed by the definition of God in the Old Testament as "I am That I am" (Exodus 3:14), and of course, theologically stressed through the formula: "The Trinity in Unity and Unity in the Trinity" ${ }^{\prime 6}$ which includes perfect personal communion and love. The existence of God does not depend on anything, not even His Being or Nature, for they do not make His existence obligatory. His absolute will and liberty is realized forever as love and triumphal communion. Thus, the real meaning of Divine Existence is "to be loved"; that's why love in its true meaning implies sharing, and it involves rational, conscious and free subjects capable of receiving and responding to the action of love, namely angels, and especially men.

Creation and man represent the environment through which the entire love of the Holy Trinity is manifested. The Holy Trinity is, by and large, the fullness of existence and of love. God the Father fully and overseas loves the Son as the fruit of perfect union, "I and the Father are one" (John 10:30) ${ }^{7}$. The God Son participates in the Father's Being as God, having His own hypostasis, manifesting at the same time His gratitude and benevolence to the infinite love of the Father. The Love of the Father to the Son also takes part in the joy of coexistent eternity, which proceeds from the eternal nature of the Father, and which has the superhuman existence of the Father, namely the third Divine Person, i.e. the Holy Spirit. Thus the Father is the source of the triumphal love, the Reflexion and the answer of love, and the Holy Spirit the gladness to the love of the Father and of the Son. Love is a personal action that reveals itself in communion; therefore, the main result of love is union and unity. The Paradox of the Trinitarian Persons consists in the fact that their love is perfect, which makes their union full, each person revealing to one other and having the same Being: "I am in the Father and the Father is in Me" (John 14:10) - says our Saviour. But the Father and

\footnotetext{
${ }^{6}$ Sf. Ioan Scăraru, Scara Raiului (Ladder of Paradise), XXV 14, transl. by Rev. Prof. D. Staniloae, in Philocaly, vol. IX, IBMBOR, Bucuresti 1980, p. 302

${ }^{7}$ Tertulian, Adversus Praxeam, chap. 10., P.L., II,188B: „Habet necesse est Pater Filium, ut Pater sit, et Filius Patrem, ut Filius sit”, compared with St. Cyril of Jerusalem, Cateheza, VII, 5; P.G. XXXIII.609B.
} 
the Son and the Holy Spirit decide from eternity that the existence they enjoy, be shared with other conscious and free existences, so that they participate in the infinite happiness and the gladness of the entire existence, in order to make known the love that characterizes Divine Being, love flowing over whole creation. God the Father, as the perfect Person, is the source

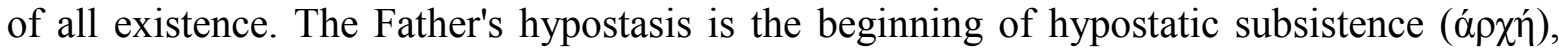
but not the being or the common Nature of the Holy Trinity. Thus this Hypostasis is the source of the Divine Being, which is in the Son and in the Holy Spirit. The Father's monarchy is seen in the fact that $\mathrm{He}$ is the beginning of all, so that the work of the Holy Trinity is a single one, having only one will, and consequently a single work. Therefore, in the verily act of creation, the entire Holy Trinity is present:

\begin{abstract}
,each is and is working in every one, it is obvious that working the Father also works the Son as His natural and physical and hypostatic Power, and by working the Son, the Father also works as the source of the creative word that naturally exists in The one born of Him, like the fire and the heat from Him ...," 8 As the Saviour shows: "My Father is working until now, and I am working." (John 5:17).
\end{abstract}

The biblical account does not propose a timeline, but a functional concentric perspective, so the Book of Creation should not be regarded as a manual of geology or cosmology. The order of the days of creation is logical, aiming to affirm the plan and direct involvement of God in the bringing into existence and organizing of the universe. The biblical account of the creation of the world and of man is presented in three realities that must be understood in a unitary way:

1) The very short one that is the one from Genesis (1:1) "In the beginning, God created the heavens and the earth." This indicates God's work "at the beginning," and places the earth in relation to the whole of the universe 9 . The infinite love of the Father to the Son in the Holy Spirit is now manifested in history, which enables Him to update himself in a concrete way outside of the Holy Trinity (ad extra) through the act of will and love, not only of humility or kenosis as Russian theologians have put it ${ }^{10}$. Therefore, the expression "in the beginning (en arhe) God made heaven and earth" (Genesis 1:1) indicates the first moment of the world's feast and all that exists besides God, namely an exit from the absence of existence. At first, when the creative act occurs and the creation comes to life, indicates both the beginning of God's descent in time and the beginning of the time that takes place with creation through the creative power of God. From this moment on, the discovery of the divine plan takes place through its application.

St. Maximus the Confessor claims that within the creation are inserted the divine rationale or the rays of the Logos (Supreme Reason), which reveals the very reality of the transcendental Divine presence and existence.

\footnotetext{
"He who does not limit the nature of those seen only on the horizon of the senses, but intelligently searches the reason of every creature with the wise mind, discovers God, learning their cause from the greatness of things themselves"11.
}

\footnotetext{
${ }^{8}$ St. Cyril of Alexandria, Comentariu la Evanghelia Sfântului Ioan, I, transl. by Rev. Prof. D. Stăniloae, in P.S.B., 41, IBMBOR, Bucharest, 2000 p. 59

${ }^{9}$ Paul Davies, The Mind of God: The Scientific Basis for a Rational World, New York: Simon \& Schuster, 1992, p. 66

${ }^{10}$ Sergei Bulgackov, Orthodoxy, transl. by N. Grosu, Paidea, Bucharest, 1994 and P. Evdochimov, Orthodoxy, transl. by Dr. Irineu Ioan Popa, IBMBOR, Bucharest, 1996.

${ }^{11}$ St. Maximus the Confessor, Quaestiones ad Thalassium, P.G. 90, col. 756A
} 
The rationality of creation is contained in the eternal counsel (the plan of God) as the potential of all created ones. Divine wisdom imparts to the creation rationality through which all must be conducted. According to St. Maximus the Confessor, the universe and any part of

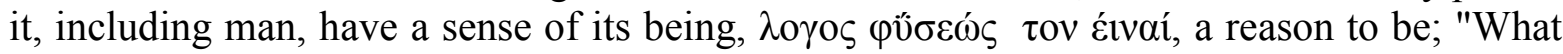
is," which makes possible the definition and the meaning of being, as well as the connection between man and God, created and uncreated. The rationale of encompassing divine intent as an informational structure in which God's power, embodied actively and temporally in creation, operates. Reason of appearing as a sum of possibilities on structure, being and

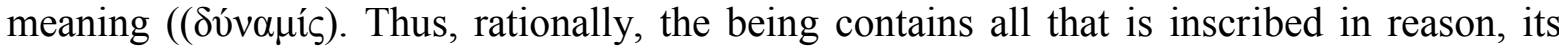
possibilities materializing in the mode of being, or movement - the natural physical movement, but not according to the wisdom and the presence of the Creator Logos, through uncreated divine energies.

„The God Father creates the universe looking the icon of Christ. And because Christ is a theandric existence, no moment of the history of creation takes place outside of this paradigm, or otherwise than through an act of synergy ... In Christ, is revealed this principle and the ultimate form of the world" 12 .

Thus, the world has the cause of the one God who has the unsteady stability, which calls and attracts those created by the endless overflow of uncreated divine energies.
„One of the earliest theological formulations of a 'cosmic Christ' can be traced back to the second century. Irenaeus of Lyon speaks of Christ's work of atonement in terms of 'recapitulating' or 'summing up' all of humanity in Him. This understanding of the cosmic redemption of Christ has been the dominant Christological view in Eastern or Greek Christianity up until the present day"13.

Logos-ness $\left(\operatorname{logonos} t^{14}\right)$ means an indelible and eternal connection between creation and holiness, between Creation and Incarnation, a connection made by Christ in the Holy Spirit.

„Creation through the Logos thus implies, after St. Maxim the Confessor, not only a positive evaluation of creation but its inclusion in the intent of universal unification based on the Incarnation of the Logos, in which all the rationale of things is hidden"15.

The Fathers of the Church talk of the eternal reasoning of the things contained in Christ, the Word of God, understanding by them and these ever-higher meanings hidden in them, and they are surprised, with the help of the Supreme Word, also of the human reason that surprises the rationale of things in strict sense. Sometimes they distinguish the meaning of the work (noem) from its strict (logos) reason. St. Athanasius the Great, starting from harmony and the orderly creation, highlights the rationality of the universe, stating that: ,the creation shows and proclaims the Master and its Maker through its order and harmony as letters..."16 which shows that the whole creation is a rational being, a reflex of the Logos Reason and Divine Word. The rationality of creation is given by the fact that it carries the imprint of the supreme Logos (reason). Between creation and the divine Logos there is an

\footnotetext{
${ }^{12}$ Andrei Kuraev, Sfinţii Părinţi, Despre originea şi destinul cosmosului şi al omului... transl. by Rev. Ioan Ică jr., 2nd edit., Deisis, Sibiu 2000, p. 240.

${ }_{13}$ Alexander Chow, 'Wang Weifan's Cosmic Christ'. Modern Theology. (2016), 10.1111/moth.12260

${ }^{14}$ Archim. Iustin Popovici, Omul şi Dumnezeu-Om, transl. by Rev. Ioan Ică and Deac. Ioan Ică jr., Deisis, Sibiu 1997, p. 44.

${ }^{15}$ Lars Thunberg, Microcosm und Mediator. The Theology of Maximus the Confessor, Lund, 1965, p. 83.

${ }^{16}$ St. Athanasius the Great, Despre intruparea Cuvântului, III, 3, in «PSB» 15, IBMBOR, Bucharest, 1987, p. 69
} 
ontological connection because each part of creation receives life from Him having an eternal reason in $\mathrm{Him}^{17}$.

To express the relationship between the Creator and the universe, Saint Maximus the Confessor conceives the Logos as its centre and unity. The whole creation carries the mark of His reason ${ }^{18}$. The world is a set of reasons (logoi) that are established and maintain a direct connection with the Creator Logos. As St. Maximus shows, the creatures exist as potential in the plan of God only, and their present existence is in time, but their temporal existence is not autonomous (that is, the world does not self-centred), but theonomic, it calls the latter, updated ones - logos, and those in potency - noema.

„Paradoxically, the creatures are one in the One Logos, which, however, is superficial and above participation. Thus, reasons are not the same with God's being, nor with the things of the created world"19.

Remaining faithful to the distinction between nature and energy - divine grace as a work of God's will, Saint Maximus manages to build a genuine ontology of creation that transcends the transcendence of the God Person, a perfect idea later perfected by St. Gregory Palamas. God creating things as plasticizers of His reasons - as Father Stăniloae says ${ }^{20}$ gave man reason as a means of knowledge by which he comes into contact with them, and through them he shares the love of the Creator. In the spirit of those affirmed, the world is distinct from God, but it is not separated from Him, neither in its existence, its meaning, nor in its rational structure.

Creating of the world "ex nihilo" (from nothing) is based on the love of God, therefore the world is His gift seen as a reality of harmony and communion (2 Maccabees 7:28). Creation is a medium of uncreated divine energies. According to the divine revelation, the world is not an emanation from the divine Being, nor is it modelled from a pre-existing matter, as Plato claimed. In pantheistic conceptions God is identified with the world, because the creative or modelling deity of matter is conceived as impersonal. If God were not a Personal Existence (tri-personal), then the created man would not have the same status as personal being, but can be "something" that, after a series of evolutions, will attain perfection, but unconsciously through the world, as, for instance, in the Asian religious conception of nirvana - the merging into the Great All. This idea makes man's conscious relationship with divinity impossible since his will-to-be forced man is reincarnated to ultimately reach nirvana, and on the other hand, he excludes his freedom from being destined to fusion with the universe. Also, the theory of pre-existence of matter limiting God's omnipotence has no logical arguments. If God needed a matter to create, it means $\mathrm{He}$ is not Absolute, Almighty, and free, but weak and limited. The dualist materialist-dualist argument (God and matter) is contradictory and impermissible because it leads to a reciprocal limitation of the two realities with the following consequences: 1. God, as Absolute Being, is no longer infinite (super temporal) and consequently somewhere God would end up and matter would begin. 2. Matter would be absorbed by God or emanate from Him (and then we ask ourselves why it is not the perfect world?). 3. God would be circumscribed by matter (i.e. matter would limit and absorb God, and consequently God would be matter). The

\footnotetext{
${ }^{17}$ St. Augustine, De Genesi ad literam, II; P.L.XXXIV, col.268

${ }^{18}$ St. Maximus the Confessor, Ambigua, in «PSB», 80, IBMBOR, Bucharest, p. 84.

19 John Meyendorff, Teologia bizantină (Byzantine theology), transl. by Rev. Prof. Dr. Alexandru I. Stan, IBMBOR, Bucharest, 1996, pp.179-180

${ }^{20}$ Rev. Prof. Dr. Dumitru Stăniloae, Teologia dogmatică ortodoxă (Orthodox Dogmatic Theology), vol. II, 2nd edit., IBMBOR, Bucharest, 1997, p. 7.
} 
teaching of Saint Gregory Palama about uncreated energies with the distinction between being and divine energies helps us to understand that the rationale of matter is grace, matter as science states - is essentially condensed energy, being the fruit of grace or unclean divine energy, as Christian theology affirms ${ }^{21}$. That is why God (as Absolute Pure Being is not confused with matter), through the uncreated gracious energies is transcendent and immanent, Almighty, Over-spatial, Supra-temporal (logically, there cannot be two realities of eternity, because they would limit each other) because it is not subject to any constraint or internal or external requires. Therefore, the only argument underlying the existence of the world is the absolute and unconditional love, specific to the Holy Trinity.

2) The second account of the biblical account of creation (Genesis 1:2-2:3) describes the various chronological phases of the history of the world in which the great wisdom of God, who creates all, as a palace, to be the emperor - the man. The biblical account shows that every new occurrence of a new order in existence, every new creation, expresses the power of the word of God "to be".

The first day of creation (Genesis 1:2-5) shows the creation of the earth "for the earth was without form and void, and darkness was over the face of the deep." (Genesis 1: 2). This first day tells us how the Creator puts into his work his eternal plan of the world; it appears as an update of his thinking. The fact that the earth was empty and void, discovers that a wise Creator was required to give him the beauty and shine he now has, to remove the depth of the water and the void to fill it with His joy, that is, the Holy Spirit - the divine energy. That is why in patristic thinking:

\begin{abstract}
„The Spirit is fine as water, because the water is fine, the Spirit over the waters fed water ... (and water) penetrates and nourishes the earth, gives it the germination power, so the Spirit over the waters did not rest...,22.
\end{abstract}

Through Him was carried over the will of the light. Saint Ephraim the Syrian says:

„The Holy Spirit warmed the waters and made them fruitful and able to conceive, like the bird when it sits on the eggs, with its wings spread and warming them with its heat, making them fruitful..."23.

St. Basil the Great, quoting this Hexaimeron, states that the Spirit gave life to the water, or made the ones in the latent state potentially present, and St. John Chrysostom concluded stressing out that it was present in the water:

\footnotetext{
„A lively energy; And it was not a mere standing and motionless water, for what is still motionless is certainly useless". ${ }^{24}$
}

The life was present from the very first moment, says Louis Pasteur, who demonstrated the fundamental law of biology, according to which every living being comes from a living thing. The presence of the Holy Spirit over the waters, as the Greek expression shows - behaves highlights the continuous aspect through which the Holy Spirit sanctifies and gives life. In this deep of water, light appears (Genesis 1: 3,4), and also day and night.

\footnotetext{
${ }^{21}$ Keith Ward, God as a Principle of Cosmological, Explanation, edit. by Roberth Russell, Nancey Murphy \& C. J. Isham, Notre Dame, Vatican Observatory and University of Notre Dame, Press, 1993, pp. 248-249.

${ }^{22}$ St. Augustine, Confessiones, transl. by Ion Barbu, 2nd edit., IBMBOR, Bucharest, 1994, p. 395

${ }^{23}$ St. Ephraim the Syrian, Tâlcuiri la facere, The Fathers of Church, New York, 1961, pp. 286-287

${ }^{24}$ St. John Chrysostom, Omilii la Facere, I; III,1, transl. by Rev. D. Fecioru, in «PSB», no. 17, IBMBOR, Bucharest, 1987, p. 94
} 
In patristic thinking the light from the beginning was spread everywhere, not being locked in a particular place, it was spreading the darkness, but anticipating the coming of the night.

„Then day and night were not due to the movement of the sun, but ... according to God's appointed measure ... the air was full of light ... the nature of the light being diaphanous ... the ether being more pleasant, and the brighter waters, because they caught the reflex of light" 25 .

God called the day as the end of the night to be an order and a sequence in the things seen. Concerning the light, the Sacred Scripture, the unseen world of the angels who dwell in heaven, or in the heaven of heaven, as David says (Ps. The creation of the unseen and implicit world of angels took place before the creation of the seen world (Luke 1:26).

From day two to the sixth day of creation (Genesis 1: 6-25), God-Creator brings into existence by His word all that exists, putting in every love and rationality. On the second day, God made the strength, that is, the celestial vault, dividing the waters from above into the lower ones, at which time the organization of matter began.

On the third day God separated the waters from the dry land, making the oceans, seas, rivers, and earth appeared with all sorts of plants according to their kind.

„It was not said of the water that God did; But he said that the earth was unseen ... not because it could cover the fire or the air, but because the liquid matter had not yet been in its place ...the earth had birth pains, the birth of all thanks to the power put into it by the Creator and only wait the time appointed, that at his command bring to light those spawned"26.

The Fourth Day of Creation (Genesis 1:13-19) presents the making of the great and small enlighteners (sun, moon stars), and their laying on the power of heaven, to enlighten the earth day and night. The creation of the sun on this day aims at strengthening the faith in Creator, and discovers that the sun is not a deity, as many misconceptions of mankind had expressed after the fall into sin, which honour creation instead of the Creator. In conclusion, God is the Creator of the sun, He is the light without evening, the One without Beginning and End.

On the fifth day of creation, God made the living creatures of the water and the birds in the air, each by their own kind, blessing them to increase and multiply (Genesis 1: 20-23).

On the sixth day, God made all the great animals, the creepers, the wild beasts, the domestic animals, all by their kind, and then the man (Genesis 1: 24-31). Each day of creation ends with the finding that all created ones are very good.

„That this perfect kindness refers to every creature in part, it is clear from the very admiration, which is to say emphatically, that in the case of that good nothing was missing so that it was not considered to be perfect" 27 .

Creation relates to the mission of man, and man to God, because the world has been made to be inhabited and coordinated by man (Isaiah $45: 18$ ).

3) The third account of the biblical account (Genesis 2: 4-25) is less systematic and chronological, but it is centred on man. This is essential for theological argumentation. Man is created by direct act of God; he is the direct work of divinity. The creation of the Holy

\footnotetext{
25 St. Basil the Great, Omilii la Hexaimeron (Homilies at Hexaemeron), II, VII, transl. by Rev. Prof. D. Feciorul in «PSB», no. 17, IBMBOR, Bucharest, 1986, p. 93

${ }^{26}$ St. Basil the Great, Homilies at Hexaemeron, II, 3, pp. 87-88.

${ }^{27}$ St. Gregory of Nyssa, Cuvânt apologetic la Hexaimeron..., transl. by Rev. T. Bodogae, in «PSB», no. 30, IBMBOR, Bucharest, 1998, p. 110.
} 
Trinity takes place: "And God said, «Let us make man in our image, after our likeness. And let them have dominion over the fish of the sea and over the birds of the heavens ... and all the earth" (Genesis 1: 26). Of all creatures, God creates him specially only; he is not the result of the divine commandment, for the earth was not able to produce a being endowed with reason, freedom, conscience and will, but only God through its great power and Love, it does in the image of His Glory, giving him the likeness to which they must reach through their own work.

Analysing the scriptural text, we see the distinction between the singular "and $\mathrm{He}$ said" and the plural "Let's make," man (singular), in our own (plural) image and likeness, we come to the conclusion that man is a reflex of the ternary icon of "the unseen God" (Colossians 1: 15), being created in the image of Christ. The "divine icon" of man is an ontological datum of human nature, while likeness concerns the realization of the image. The clarification of this statement is given by the conclusion of the Bible after the creation of the woman (Eve): "So God created man in his own image, in the image of God he created him; male and female he created them" (Genesis 1:27) without reminding the likeness, the latter being the goal of his life. The distinction between masculine and feminine, of course, has no implication on the image of God in man, for God is not divided into masculine and feminine; therefore, His image extends over the whole human nature personally covered by man and woman. Chapter 2, verse 7 of Genesis relates the way of man's creation: "then the Lord God formed the man of dust from the ground and breathed into his nostrils the breath of life, and the man became a living creature..." Thus, human nature is dually constituted i.e. soul-body, being penetrated by grace, by life's breath. The man (anthropos) is the personal being composed of the body (soma), and the soul (psyche, anima) or the rational and immortal part. The soul created by God is presented as the reality of life, which leads the body with which it forms a harmonic unity, with the attitude of being untouchable and not material (quantitative) endowed with reason, self-consciousness and free will through which perceives the organic body, immortal through the divine, immaterial, unique and united, indelible and unrepeatable grace, which through its faculties offers and directs human nature to spirituality.

The Book of Faith shows that God has not put on the woman - as in Adam - the breath of life, but has taken part of his body and made another human being: Eve. The man-woman pair formed for love and procreation is a necessity of the human nature created by God. Man and woman have the same biological, ontological identity (of the unique human being), but after the constitution of the body, there are some differences that generate gender-specific attributes of both masculine and feminine. This distinction does not imply the divine image because they are equal in terms of ontological qualities and moral aspects and virtues imply full personal involvement, freedom and responsibility, making progress or material and spiritual regression possible.

\section{The man living icon of the love and beauty of God}

Man is the psycho-physical being created by love in the image of God that has in its rationality both the divine origin and the purpose to which it is to be directed, namely the full existence. The creation of man in the image of the Son of God implies the natural implementation in his nature, of all the necessary capabilities and tools by which to do likewise with God. The divine human constitution or "creation in the image of God" actually means participation in the Archetype. This is the Christian foundation through which man differentiates himself from other creatures from the other beings. Sacred Scripture defines 
the nature and role of man by the expression "image and likeness." Man was created by God through a special act, which gives him a special status: "And God said, Let us make man in our image and likeness" (Genesis 1: 26-27; 9.6).

By and large, this is the definition given by the Old Testament to man. Taking into account the free and rational nature of man, the Sacred Scripture presents it in different states, which correspond to the moral reality in which it is found as a result of the relationship with God. Thus, we have an incomplete positive state before sin; a negative state by altering the face of sin, and a positive state that is about the eschatological, made by Christ in which humanity is renewed and magnified.

Etymologically, the term "icon" derives from the Hebrew word "telem" (goal, shadow, reflection), and from the Greek cíkóv / image, designating a plastic image such as an effigy or a statue understood in the Old Orient as a manifestation or as an incarnation of the represented one, as evidenced by the Wisdom of Solomon (15: 14-18). As for the definition of the notion of the image and its evolution, the Holy Fathers and Church' writers have identified it, either with a part of human nature, of course, the spiritual one - the soul or the body, or the correct theological sense which pertains to man as a whole (Soul-body), and not to one of his rational or affective faculties.

The word "Eíkóv" (image) defines what man is naturally ontological in himself. Natural in the original state of the image reflects in itself the state of grace, the grace being the medium in which the human-face is manifested, being intrinsic human natures. By the term "image" is shown the ontological gift created by God, without the man having any input, and by the likeness it is shown what man can be, what must be done by the fulfilment of the image, i.e. the acquisition of holiness.

Specific to theological logic, man is the personal being characterized by reason, will and freedom, by the responsibility of his deeds. Man by what he accomplishes in the material and spiritual realm becomes a personality. The ontology of nature, nature, species of which it is part is embodied in person:

\begin{abstract}
"Common and universal are also attributed to those who are under them. Common is the being, as a species, and the particular hypostasis. It is special not because it has a part of nature, because it has no part of it, but it is private in number, for example: the individual. The hypostases are different in number and not by nature. The being is asserted by the hypostasis, because the being is perfect in each of the hypostases of the same species. That is why the hypostases do not differ from one another in terms of being, but in terms of accidents, which are characteristic traits. However, characteristic features belong to the hypostasis and not to the flesh. The hypostasis defines: being together with accidents. That is why the hypostasis possesses the common with the individual and the existence itself. The being, however, does not exist in itself, but is considered to be hypostasis" 28 .
\end{abstract}

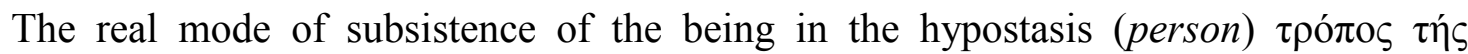
îjáp $\xi^{\varepsilon} \dot{\omega} \varsigma$ way of parable is the concrete state which relates to God has the same meaning, and shows that the being does not exist without the hypostasis and the hypostasis without being. As for the being and its distinction from hypostasis, St. Basil the Great says:
„We therefore support the following: what it is stated in its own way is shown by the hypostasis. Indeed, when you say, Man, in your ear - by the undefined specification of this word - is a scattered idea, so if nature is indicated by this appointment what is meant and which has indicated it by its name is not specified. On the contrary, when you say Paul, then you look exactly at the being indicated by that name. This is the hypostasis: not the

\footnotetext{
${ }^{28}$ St. John Damascene, Dogmatics, II, transl., intr., notes and indexes by Rev. D. Fecioru, IBMBOR, Bucharest, 2001, pp. 124-125.
} 
undefined notion of the substance, which finds no stability in the community of the specified work, but that notion defines and defines what is common and indefinite in a particular object determined by its own attributes. Ousia (being) is the fond of the common nature of several individuals of the same species, for example: humanity, and hypostasis is the concrete subconscious individual, Peter, Paul, John ... So when two or more people are taken together, for example, Paul, Silvan ... we will not give a special definition for Paul, another for Silvan and another for Timothy, but the terms that will help us to identify Paul will be also fit for the others who are in them of the same being(ópoovoíoí) because they are specified by the same definition of the substance “29.

The term hypostasis, as described by Saint Basil the Great, means the person in dialogue, or the person bound by communion with another person. So a first characteristic of the person is love and communion. The human existence has been imprinted with God and human nature, man being created in the image of God and so framed within the boundaries of love, but as a conscious and living subject, yet full of freedom from the boundaries of his own nature. Through the choices made, and especially through the relationship with God, the man helped by far reaches true freedom. Thus, the ontological meaning of "to be" from the human point of view means TO BE GOD-LIKE, TO BE GOD AFTER GRACE. Man cannot acquire the state of perfection than in working with God and by giving up the evil will at the same time as giving to others who are themselves God's icons. What corresponds to the image of God is not a part of his being, but the person who encompasses the whole of the nature, as Leontius of Byzantium shows in the fourth century, through enypostasis

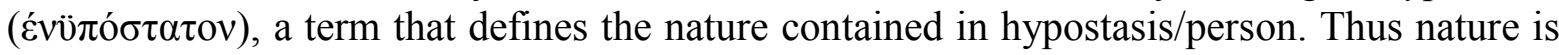
the content of the person and the person the existence of the nature.

The person is a dynamic ensemble, not an automatic mechanism, it is the mark of authenticity and uniqueness, and it hypothesizes the being with existence in itself, materialized by a conscious and free being, capable of communion and relationship. The dual human being, made up of body and soul, is in constant quest, in constant kneading and tension, by relationship and communion. Through man the soul tends to the spiritual, to the knowledge of God, through the flesh man is bound to the whole world.
, In the fact that man knows the universe and exceeds his knowledge, in his quality of unity, spirit and body, keeping in his soul and putting on him the spiritual seal, it is shown that the body participates in the subject quality or person as man. The body is thus human and object given and participant in its quality of subject" 30 .

The centrality of the theology the "icon of man" is Christ, a teaching emphasized by Apostle Paul, which shows that

\begin{abstract}
„Who is the image of the invisible God, the firstborn of every creature: For by him were all things created, that are in heaven, and that are in earth, visible and invisible, whether they be thrones, or dominions, or principalities, or powers: all things were created by him, and for him: And he is before all things, and by him all things consist. And he is the head of the body, the church: who is the beginning, the firstborn from the dead; that in all things he might have the pre-eminence." (Colossians 1: 15-18).
\end{abstract}

Man's aspiration to God cannot be understood without the breath of life of the Holy Spirit through which appears in man a "Thou-God" relationship, identified by the divine image.

According to Christian thinking, God creates from nothing a partner for dialogue in a biological organism through the spiritual breath of grace, namely man. From the beginning,

\footnotetext{
${ }^{29}$ St. Basil the Great, Homily XXXVIII, 2 -3, transl. by Rev. T. Bodogae, in «PSB», no. 12, Bucharest, 1998 , p. 178.

30 Rev. Prof. D. Staniloae, Chipul nemuritor al lui Dumnezeu, I, 1,3 Mitropolia Olteniei, Craiova 1987, p. 34
} 
the real mode of human existence is to participate into divine life and spirituality, a possibility given by its special constitution in the image of God:

\begin{abstract}
„Thus the icon is the horizon in which the truth about being is revealed, not as a simple

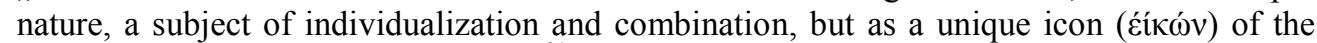
totality and universality of the being " "31.
\end{abstract}

By Christ, man knows and receives the beauty of God, one in being, and one in God, the Father, the Son, and the Holy Spirit. Christ the Son of God highlights the character of the relational, dialogical, human-specific being, conceived in the reflection that transcends like the mirror of another being. Marching on this idea, Saint Gregory of Nyssa bases man's degree of kinship with God ( $\sigma 0 ́ \gamma \varepsilon ́ v \varepsilon i ́ \alpha)$, affinity between the man icon and model, man's participation in divine life in which he enjoys infinity and enlightenment of divine spirituality, namely, deification. This state of communion with God involves $\mu \varepsilon \tau \alpha o v \sigma i \alpha \tau$ $\theta \varepsilon \omega v$, on the one hand, the origin of the divine man, but also the necessity to taste the immeasurable beauty and love of the Creator, which is accomplished by the derivation of the fruits of the sacrifice of Christ. All this issue of man's likeness to God is possible because there are divine elements in man, namely the image and divine energies, through which the boundary - where philosophies and humanistic sciences stop when dealing with God and man about created and uncreated, transcendent and immanent - is overcome. In the ambience of uncreated divine energies the image of God in man redefines the beauty of the Christ model. That is why man is an iconic being in accordance with theology that finds and tends to communion with God, with himself, with his fellow men and with all creation.

\title{
CONCLUSION
}

Christian cosmology and anthropology presents creation in general and man in particular, in direct relationship with Christ. The exceptional position of man in his creation, his structure and his ultimate purpose are fully discovered and made by the cosmic Christ. The transcendent and immanent principle, active in creation, is the grace of the Holy Spirit or the uncreated divine energy that sustains the entire cosmos.

The world is, in this sense, a gift of divine love, a love that he shares with man through the Holy Spirit. Love means affection and necessity of communion, fully lived through sharing and giving to others. The creation of the world and of man is the first testimony of the love of God - the Holy Trinity.

There is a very close connection between man and the world, a connection that is based primarily on his bodily and soul constitution. But more than anything created, man is the bearer of God's image, who makes him rational, free and sentimental. These manspecific traits call for interpersonal communion, for dialogue and unity, because the functions of the image are the objective foundation that by its dynamic structure implies the likeness of God or the state of perfection, namely of deification.

\section{BIBLIOGRAPHY:}

[1] Andrei Kuraev, Sfinţii Părinţi, Despre originea şi destinul cosmosului şi al omului... transl. by Rev. Ioan Ică jr., 2nd edit., Deisis, Sibiu 2000

[2] St. Athanasius the Great, Despre intruparea Cuvântului, in «PSB» 15, IBMBOR, Bucharest, 1987

[3] St. Augustine, Confessiones, transl. by Ion Barbu, 2nd edit., IBMBOR, Bucharest, 1994

[4] St. Augustine, De Genesi ad literam; P.L.XXXIV, col.268

31 Drd. Vasile Cristescu, Caracterul comunitar al chipului lui Dumnezeu in om, in „Sudii Teologice” Nr.1-2, Bucharest, 1992, p. 96 
[5] St. Basil the Great, Homily XXXVIII, transl. by Rev. T. Bodogae, in «PSB», no. 12, Bucharest, 1998,

[6] St. Basil the Great, Omilii la Hexaimeron (Homilies at Hexaemeron), transl. by Rev. Prof. D. Feciorul in «PSB», no. 17, IBMBOR, Bucharest, 1986

[7] Bulgackov Sergei, Orthodoxy, transl. by N. Grosu, Paidea, Bucharest, 1994

[8] Chow Alexander, 'Wang Weifan's Cosmic Christ'. Modern Theology. (2016), 10.1111/moth.12260

[9] Chrysostom St. John, Omilii la Facere, transl. by Rev. D. Fecioru, in «PSB», no. 17, IBMBOR, Bucharest, 1987

[10] Cristescu Vasile, Caracterul comunitar al chipului lui Dumnezeu in om, in „Sudii Teologice” Nr.1-2, Bucharest, 1992

[11] St. Cyril of Alexandria, Comentariu la Evanghelia Sfântului Ioan, I, transl. by Rev. Prof. D. Stăniloae, in P.S.B., 41, IBMBOR, Bucharesti

[12] St. Cyril of Jerusalem, Cateheza, P.G. XXXIII.609B.

[13] St. John Damascene, Dogmatics, transl., intr., notes and indexes by Rev. D. Fecioru, IBMBOR, Bucharest, 2001

[14] Davies Paul, The Mind of God: The Scientific Basis for a Rational World, New York: Simon \& Schuster, 1992

[15] St. Ephraim the Syrian, Tâlcuiri la facere, The Fathers of Church, New York, 1961

[16] Evdochimov P.., Orthodoxy, transl. by Dr. Irineu Ioan Popa, IBMBOR, Bucharest, 1996.

[17] Francis Peters E., Termenii filosofiei grecesti (The terms of Greek Philosophy), 2nd edit., Bucharest, Humanitas, 1997

[18] Gregory St. of Nyssa, Cuvânt apologetic la Hexaimeron..., transl. by Rev. T. Bodogae, in «PSB», no. 30, IBMBOR, Bucharest, 1998

[19] Haught John F., Ştiinţă şi religie (Science and Religion), Eonul Dogmatic, Bucharest, 2002

[20] John Meyendorff, Teologia bizantină (Byzantine theology), transl. by Rev. Prof. Dr. Alexandru I. Stan, IBMBOR, Bucharest, 1996

[21] Laertios Diogenes, Viaţa şi doctrinele filosofilor (Life and Doctrines of the Philosophers), Academia Română, Bucharest, 1963

[22] St. Maximus the Confessor, Ambigua, in «PSB», 80, IBMBOR, Bucharesti, 1980

[23] St. Maximus the Confessor, Quaestiones ad Thalassium, P.G. 90, col. 756A

[24] Narly C., Antologie ftlosofica, (Philosophical Anthology), Bucharest, Casa Scoalelor, 1943

[25] Pierre Jean Lonchamp, Stiinţă şi credinţă (Science and Faith), transl. by Magda Stavinschi, Eonul Dogmatic, Bucharest, 2003

[26] Popovici Archim Iustin., Omul şi Dumnezeu-Om, transl. by Rev. Ioan Ică and Deac. Ioan Ică jr., Deisis, Sibiu 1997

[27] Sallis John, Being and Logos-Reading the platonic dialogues, Bloomington, Indiana University Press, 1996

[28] St. Ioan Scăraru, Scara Raiului (Ladder of Paradise), transl. by Rev. Prof. D. Staniloae, in Philocaly, vol. IX, IBMBOR, Bucuresti 1980

[29] Staniloae Rev. Prof. D., Chipul nemuritor al lui Dumnezeu, (The Immortal Icons of God) Mitropolia Olteniei, Craiova 1987

[30] Stăniloae Rev. Prof. D., Teologia dogmatică ortodixă, (Orthodox Dogmatic Theology) vol. II, ed. a IIa,I.B.M., Bucureşti 1997

[31] Tertulian, Adversus Praxeam, P.L., II,188B

[32] Thunberg Lars, Microcosm und Mediator. The Theology of Maximus the Confessor, Lund, 1965

[33] Ward Keith, God as a Principle of Cosmological, Explanation, edit. by Roberth Russell, Nancey Murphy \& C. J. Isham, Notre Dame, Vatican Observatory and University of Notre Dame, Press, 1993 